\title{
Angiotensin II during Experimentally Simulated Central Hypovolemia
}

\author{
Theo Walther Jensen ${ }^{1 *}$ and Niels Vidiendal Olsen ${ }^{1,2}$ \\ ${ }^{1}$ Department of Neuroscience and Pharmacology, The Health Faculty, University of Copenhagen, Copenhagen, Denmark, \\ ${ }^{2}$ Department of Neuroanaesthesia, The Neuroscience Centre, University Hospital of Copenhagen (Rigshospitalet), \\ Copenhagen, Denmark
}

Central hypovolemia, defined as diminished blood volume in the heart and pulmonary vascular bed, is still an unresolved problem from a therapeutic point of view. The development of pharmaceutical agents targeted at specific angiotensin II receptors, such as the non-peptidergic $A T_{2}$-receptor agonist compound 21 , is yielding many opportunities to uncover more knowledge about angiotensin II receptor profiles and possible therapeutic use. Cardiovascular, anti-inflammatory, and neuroprotective therapeutic use of compound 21 have been suggested. However, there has not yet been a focus on the use of these agents in a hypovolemic setting. We argue that the latest debates on the effect of angiotensin II during hypovolemia might guide for future studies, investigating the effect of such agents during experimentally simulated central hypovolemia. The

OPEN ACCESS

Edited by:

Junjie Xiao,

Shanghai University, China

Reviewed by:

Nazareno Paolocci, Johns Hopkins University, USA Franco Laghi-Pasini,

University of Siena, Italy

*Correspondence:

Theo Walther Jensen theo.walther.jensen@gmail.com

Specialty section:

This article was submitted to General

Cardiovascular Medicine,

a section of the journal

Frontiers in Cardiovascular Medicine

Received: 17 December 2015

Accepted: 18 February 2016

Published: 03 March 2016

Citation:

Jensen TW and Olsen NV (2016) Angiotensin II during Experimentally Simulated Central Hypovolemia.

Front. Cardiovasc. Med. 3:6. doi: 10.3389/fcrm.2016.00006 purpose of this review is to examine the role of angiotensin II during episodes of central hypovolemia. To examine this, we reviewed results from studies with three experimental models of simulated hypovolemia: head up tilt table test, lower body negative pressure, and hemorrhage of animals. A systemic literature search was made with the use of PubMed/MEDLINE for studies that measured variables of the renin-angiotensin system or its effect during simulated hypovolemia. Twelve articles, using one of the three models, were included and showed a possible organ-protective effect and an effect on the sympathetic system of angiotensin II during hypovolemia. The results support the possible organ-protective vasodilatory role for the $\mathrm{AT}_{2}$-receptor during hypovolemia on both the kidney and the splanchnic tissue.

Keywords: angiotensin II, central hypovolemia, angiotensin II receptor subtype 2, losartan, organ protection

\section{INTRODUCTION}

Central hypovolemia, defined as diminished blood volume in the heart and pulmonary vasculary bed (1), is a potentially life-threatening condition that left untreated leads to hemorrhagic shock (2). However, the therapeutic strategy for central hypovolemia is debated and still unresolved $(3,4)$. Expanding our knowledge about the hormones that act to stabilize the hemodynamic conditions during hypovolemia is essential to proposing new therapeutic strategies.

During World War II, an increase in the interest in hypovolemic shock gave rise to a large body of research on the hemodynamic effects of central hypovolemia (5-8). This research shed light on many of the now well-known hemodynamic effects of central hypovolemia and developed the broadly used experimental models for simulating central hypovolemia. There are three experimental models 
generally accepted as valid: head up tilt table, hemorrhage, and lower body negative pressure $(1,9)$. Head up tilt is an experimental model in which subjects, in the supine position, are raised to a head up position of various degrees, thereby allowing the larger part of the blood volume to move toward the lower extremities inducing an experimentally simulated central hypovolemia ( 1 , 10). Lower body negative pressure consists of a design that induces negative pressure surrounding the lower extremities thereby driving the blood from the thoracic circulation to the lower extremities. The third experimental model is the hemorrhage in animals to a point of registered central hypovolemia. Trials using these experimental models investigated the endocrine effects of central hypovolemia, uncovering the now well-established rise in epinephrine, aldosterone, and angiotensin II during the late phase of central hypovolemia (1).

Angiotensin II, the end product of the renin-angiotensin system (RAS), is a hormone involved in maintaining blood pressure. Under normal circumstances, this system works by increasing fluid intake through dipsogenic effect mediated by the subfornical organ and by retaining sodium and water by the adrenal release of aldosterone along with a direct effect on the proximal tubule (11-14).

Angiontensin II increases the activity of the sodium-hydrogen antiporter in the proximal tubule and causes a vasoconstriction of the efferent and afferent arteriole leading to a shift of the Starling forces. Both of these effects favor water and sodium reabsorption $(12,13,15)$. During central hypervolemia, angiotensin II acts as a vasopressor by inducing peripheral vasoconstriction $(14,15)$. Angiotensin II acts through four-subtype receptors label $\mathrm{AT}_{1-4}$.

In the early 90s, a growing number of pharmaceutical agents regulating the synthesis or blocking specific receptors of angiotensin II where developed. By the use of these agents during experimentally simulated central hypovolemia, it was possible to isolate different aspects of angiotensin II's effects and locate them to specific subtype receptors. The use of an antagonist of the angiotensin II receptor subtype 1 ( $\mathrm{AT}_{1}$-receptor) during simulated central hypovolemia resulted in a drop in mean arterial pressure, total peripheral resistance, and systemic vascular resistance. This lead to the conclusion that the G-coupled $\mathrm{AT}_{1}$-receptor localized in cardiac, vascular, pulmonary, renal, and adrenal tissue $\mathrm{AT}_{1}$-receptor is the main mediator of the vasoconstrictor effect of angiotensin II during hypovolemia (15-25). The role of the G-coupled $\mathrm{AT}_{2}$-receptor during hypovolemia is still not certain (15). Still no apparent studies have been carried out using a selective $\mathrm{AT}_{2}$-receptor agonist in experimentally simulated central hypovolemia. The non-peptidergic $\mathrm{AT}_{2}$-receptor agonist compound 21 is yielding many opportunities to uncover more knowledge about angiotensin II receptor profiles and possible therapeutic use.

Angiotensin II can be cleaved to Angiotensin (1-7) by the normally sparse enzyme Angiotensin Conversing Enzyme 2 (26). Angiotensin (1-7) is postulated to counteract the pressor effect of Angiotensin II and via the G-coupled Ang(1-7) receptor (26-28).

A number of studies have reported that losartan, the most common $\mathrm{AT}_{1}$-receptor antagonist, accentuated the hypotensive response to orthostatic stress compared with other $\mathrm{AT}_{1}$-receptor antagonists and angiotensin-converting enzyme (ACE) inhibitors $(18,24,25)$. Such an effect may indicate that losartan in itself have an effect beyond $\mathrm{AT}_{1}$-receptor antagonism. These results have since given rise to several different hypotheses and explanations to why losartan and other $\mathrm{AT}_{1}$-receptor antagonists have an accentuated orthostatic hypotensive effect compared with other general angiotensin receptor antagonists and ACE-inhibitors $(18,22,24,25,29)$. The studies of the effect of losartan have revived older debates on the interaction of angiotensin II with the sympathetic system. It is undisputed that angiotensin II has a blunting effect on the baroreflex, but whether this is mediated either centrally or peripherally is still disputed (30-34).

The purpose of this review is to examine the role of angiotensin II during episodes of central hypovolemia.

\section{METHODS}

The search was executed using the search terms: "((()((head up tilt) OR hypovolemia) OR Lower body negative pressure AND angiotensin) NOT thirst) NOT hypertension Filters: Clinical Trial, Comparative Study, Controlled Clinical Trial, Randomized Controlled Trial, Case Reports, English Abstract, Evaluation Studies, In Vitro, Observational Study, Twin Study))" in pubmed/ MEDLINE. The latest search was performed in October 2015. This approach provided a result of 445 articles. After applying the following inclusion criteria: studies using $\mathrm{AT}_{1}$-receptor antagonist; both human and animal experiments; articles in English, Spanish, or Scandinavian (Danish, Swedish, or Norwegian), 72 remained. Exclusion criteria were the following: diagnosis expected of essentially altering RAS during experimentally simulated central hypovolemia (e.g., hypertension); articles that did not include a model of experimentally simulated central hypovolemia. The latter also applied with a set of cut-offs, as defined at the end of this section. The search gave eight eligible articles. Further four articles were included by reference lists. This gave a total of 12 eligible articles. Of the eligible articles, five were head up tilt table, five studies were hemorrhage of animals, and two were lower body negative pressure, as shown in Figure 1. There was a relatively even distribution between the three different designs. There was a predominance of studies with animal subjects but there was no noteworthy difference in the number of subjects (see Table $\mathbf{1}$ ).

\section{CUT-OFFS AND COMPARISONS OF MODELS}

The following cut-offs are made to insure that the response to the hypovolemia models stimuli elicited a hormonal response rather than a purely baroreceptor-mediated compensation. The minimum amount of degrees raised in head up tilt table is 30 , since that seems to be the lowest tilt where non-baroreceptor response has been observed $(1,32)$. The amount of negative pressure in lower body negative pressure models needed to sufficiently simulate central hypovolemia is disputed (38). A moderately conservative cut-off is that above $-40 \mathrm{mmHg}$ the organism does not treat the design as central hypovolemia (39-42). Others suggest 


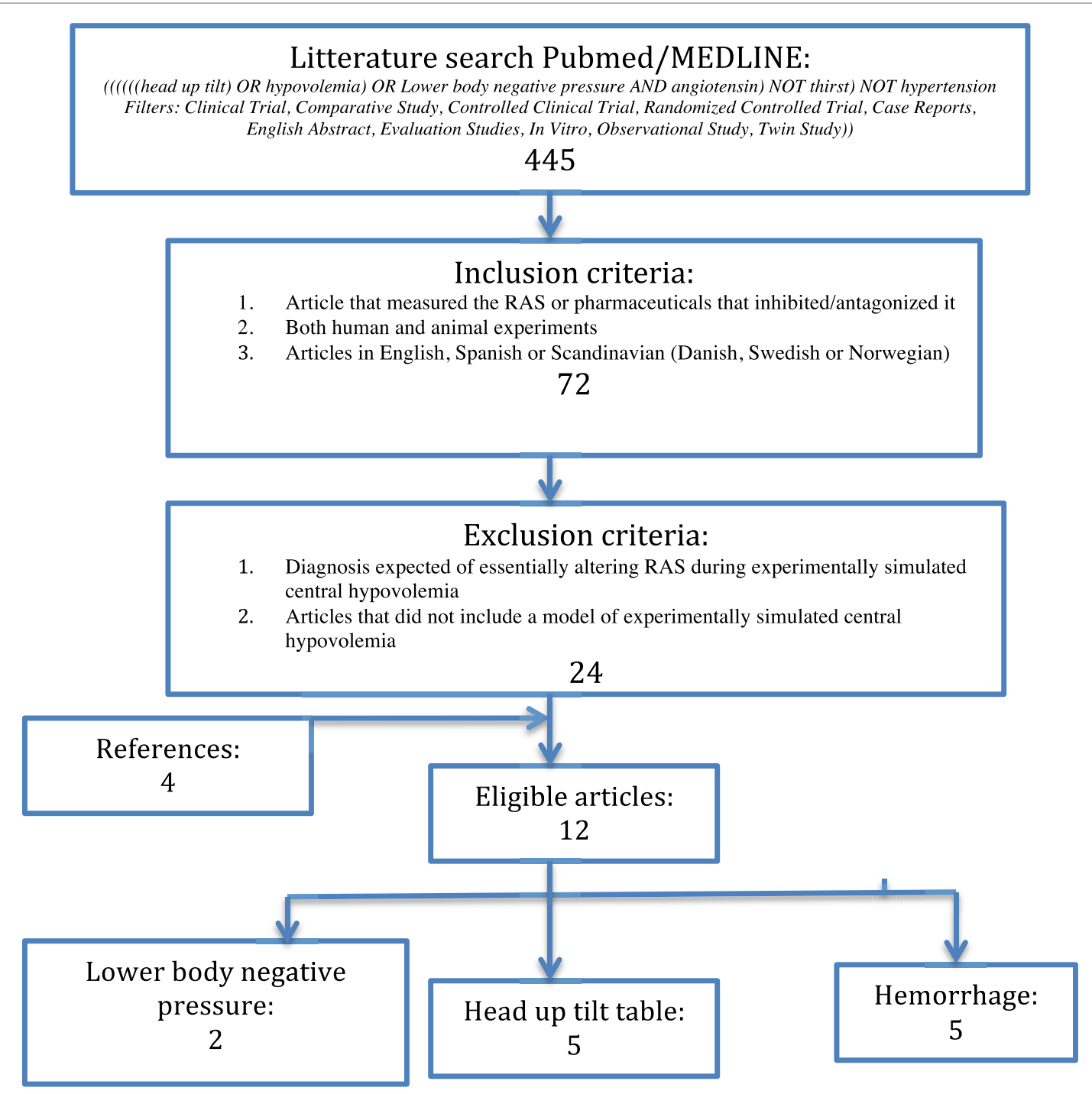

FIGURE 1 | Flowchart of study selection

$-50 \mathrm{mmHg}$ (43). This article will use the $-40 \mathrm{mmHg}$ cut-off as accepted induced pressure.

Below 20\% hemorrhage of total blood volume in some species, the carotid sinus maintains mean arterial pressure and central hypovolemia will not be observed $(44,45)$. The temporal dimension was also considered in all three models. Although there was no clear temporal cut-off, no studies were included that did not have reasonable temporal dimensions.

Two recent studies have compared the three models and have found similar results regarding conversion of degrees in head up tilt table, $\mathrm{mmHg}$ negative pressure, and percentage of total blood volume $(40,43)$. The cut-off values chosen for each of the three models of simulated central hypovolemia is similar when converted with the conversions of these two studies.

Head up tilt table tends to produce a larger fluctuation in mean arterial pressure, which might originate from an activation of vestibular control on the cardiovascular system, whereas lower body negative pressure increases heart rate relatively more. There tend to be a higher vascular resistance change in the lower, compared to the upper, body in head up tilt, compared to lower body negative pressure, which produce an equal change in lower and upper body (46).

\section{RESULTS}

Explaining the accentuated orthostatic response of losartan has lead to two general areas of interest for analysis of angiotensin II's effect during episodes of experimentally simulated central hypovolemia. One argued that, when the $\mathrm{AT}_{1}$-receptor is blocked, the rise in angiotensin II implies that there will be a corresponding increase in the stimulation of other angiotensin II receptors. Most relevant in this context is the $\mathrm{AT}_{2}$-receptor and $\mathrm{Ang}(1-7)$ $(15,20-22)$. The other argues that losartan seems to be blunting a sympathetic effect of angiotensin II $(18,22,24,25)$. 
TABLE 1 | List of eligible studies.

\begin{tabular}{|c|c|c|c|c|c|}
\hline Author & Result & Model & $N$ & Subject & $\begin{array}{l}\text { Use of antagonist } \\
\text { or inhibitor }\end{array}$ \\
\hline Aneman et al. (35) & $\begin{array}{l}\text { During hypovolemia, AT1RA animals had improved portal venous } \\
\text { blood flow and jejunal mucosal perfusion maintenance and better } \\
\text { survival rate }\end{array}$ & Hemorrhage & 20 & Pigs - landrace & AT1RA \\
\hline Bedette et al. (22) & $\begin{array}{l}\text { Lorsartan have the same AT1RA. AT1RA's kan cross the } \\
\text { blood-brain barrier and can have its effect on pre-motor neurons }\end{array}$ & Head up tilt table & $10-14$ & Rats & AT1RA \\
\hline de Moura et al. (18) & $\begin{array}{l}\text { The marked orthostatic cardiovascular response of losartan may } \\
\text { be due, in part, to an interaction of this antagonist with Ang-(1-7) } \\
\text { receptors }\end{array}$ & Head up tilt table & 24 & $\begin{array}{l}\text { Rats - male } \\
\text { Wistar }\end{array}$ & $\begin{array}{l}\text { AT1RA and } \\
\text { ACE-inhibitor }\end{array}$ \\
\hline Franke et al. (36) & $\begin{array}{l}\text { During the LBNP, GFR decreased significantly during } \\
\text { cardiopulmonary stress testing in the subjects taking the placebo } \\
\text { and remained unchanged in those under treatment with AT1RA }\end{array}$ & $\begin{array}{l}\text { Lower body negative } \\
\text { pressure }\end{array}$ & 18 & Human & AT1RA \\
\hline Hashimoto et al. (24) & $\begin{array}{l}\text { During hypovolemia losartan result in prolonged orthostatic } \\
\text { hypotensive effect compared to other AT1RA }\end{array}$ & Head up tilt table & & Rats & AT1RA \\
\hline Hatton et al. (19) & $\begin{array}{l}\text { Angiotensin II have an effect on the sympathetic system mediated } \\
\text { by the } A T_{1} \text {-recpetor. The site of action I peripherally }\end{array}$ & $\begin{array}{l}\text { Lower body negative } \\
\text { pressure }\end{array}$ & - & Cats & $\begin{array}{l}\text { AT1RA and } \\
\text { ACE-inhibitor }\end{array}$ \\
\hline Johansson et al. (23) & $\begin{array}{l}\text { Hypovolemia was seen to inhibit alkaline secretion and that } \\
\text { angiotensin II potentiated that inhibition. Furthermore, it is argued } \\
\text { in favor of a peripheral site of action of angiotensin II on the } \\
\text { sympathetic nervous system }\end{array}$ & Hemorrhage & 18 & $\begin{array}{l}\text { Rats - } \\
\text { Sprague-Dawley }\end{array}$ & $\begin{array}{l}\text { AT1RA and } \\
\text { ACE-inhibitor }\end{array}$ \\
\hline Laesser et al. (37) & $\begin{array}{l}\text { Jeujenal perfusion is accentuated by } A T 1 R A \text { and activation of } \\
\text { intestinal } \mathrm{AT}_{2} \text {-receptors may play a significant role in improving the } \\
\text { outcome of severe hypovolemia }\end{array}$ & Hemorrhage & 53 & Pigs - Landrace & AT1RA and AT2RA \\
\hline Ohlstein et al. (25) & $\begin{array}{l}\text { Losartan have an effect beyond } \mathrm{AT}_{1} \text {-receptor antagonism. With } \\
\text { accentuated orthostatic intolerance }\end{array}$ & Head up tilt table & 22 & Rats & $\begin{array}{l}\text { AT1RA and } \\
\text { ACE-inhibitors }\end{array}$ \\
\hline Pancera et al. (16) & $\begin{array}{l}\text { Losartan has inhibitory effect on the sympathetic activity and } \\
\text { maintained vagal activity }\end{array}$ & Head up tilt table & 18 & Human & AT1RA \\
\hline Ryckwaert et al. (21) & $\begin{array}{l}\text { Selective } \mathrm{AT}_{1} \text {-receptor blockade was associated with a } \\
\text { vasodilatation and a preservation of } \mathrm{CO} \text { and } \mathrm{SV} \text {. It is speculated } \\
\text { that the dilation is due to overstimulation of the } \mathrm{AT}_{2} \text {-receptor }\end{array}$ & Hemorrhage & 36 & $\begin{array}{l}\text { Piglets - farm } \\
\text { bred }\end{array}$ & AT1RA and AT2RA \\
\hline $\begin{array}{l}\text { Ryckwaert and } \\
\text { Colson (20) }\end{array}$ & $\begin{array}{l}\text { The results suggest that } A T_{2} \text {-receptor had only small if any } \\
\text { contribution to a systemic vasodilatation observed during } \\
A T_{1} \text {-receptor blockade }\end{array}$ & Hemorrhage & 18 & $\begin{array}{l}\text { Piglets - farm } \\
\text { bred }\end{array}$ & AT1RA and AT2RA \\
\hline
\end{tabular}

AT1RA, AT $T_{1}$-receptor antagonist and AT2RA, AT ${ }_{2}$-receptor antagonist.

\section{ORGAN-SPECIFIC PROTECTIVE FUNCTION OF AT ${ }_{2}$-RECEPTOR}

Initially, the hypothesis was that the overstimulation of the $\mathrm{AT}_{2}$-receptor resulted in a systemic vasodilation $(21,47)$. Ryckwaert et al. found that, when an $\mathrm{AT}_{1}$-receptor antagonist was used during 20 and 40\% total blood volume hemorrhage in pigs $(N=18)$, there was a significant fall in vascular resistance compared with ACE-inhibitors (21). Further selective $\mathrm{AT}_{1}$-receptor blockade was associated with a vasodilatation. This lead to the initial hypothesis, which seemed likely since several studies have observed that the $\mathrm{AT}_{2^{-}}$ receptor has a vasodilatory effect in some tissues $(15,38,48-50)$. However, other studies observed that the vasodilatory effect of the $\mathrm{AT}_{2}$-receptor was not dominant during hypovolemia (51). Ryckwaert et al. tested the hypothesis in a later study using both $\mathrm{AT}_{1}$-receptor antagonists, $\mathrm{AT}_{1}$-receptor alone, and together with $\mathrm{AT}_{2}$-receptor antagonists during experimentally simulated central hypovolemia. The result did not show a significant systemic difference between the two groups leading to the conclusion that there is no systemic effect of overstimulation of the $\mathrm{AT}_{2}$-receptor during hypovolemia (20).
Even though there is no evidence of a systemic role of the $\mathrm{AT}_{2}$-receptor during central hypovolemia, there is some evidence supporting an organ-specific vasodilatory role for the $\mathrm{AT}_{2^{-}}$ receptor. Examining the kidney function during experimentally simulated central hypovolemia, it is observed that $\mathrm{AT}_{1}$-receptor antagonists help maintain the GFR despite a reduction in RPF and RBF compared with controls (29). This suggests a role of the angiotensin II that is not mediated by the $\mathrm{AT}_{1}$-receptor. The relatively high expression of the $\mathrm{AT}_{2}$-receptor in the kidney, intestines, and other tissues, together with findings that the $\mathrm{AT}_{2}$ receptor antagonist increases pressure and decreases nitric oxide concentration is in favor of an organ-specific role $(15,47,52)$.

In a study in which landrace pigs $(N=53)$ underwent a $30 \%$ total blood volume hemorrhage, it was reported that survival rates were higher in the group, which were only given $\mathrm{AT}_{1}$-receptor antagonist, compared with the group given both $\mathrm{AT}_{1}$-receptor and $\mathrm{AT}_{2}$-receptor antagonists (37). The authors found that during $\mathrm{AT}_{1}$-receptor antagonism only, and hence comparative overstimulation of the $\mathrm{AT}_{2}$-receptor, the jejunal intraluminal nitric oxide output was significantly higher. During hypovolemia, 
there was a greater expression of the $\mathrm{AT}_{2}$-receptor in the jejunum. This indicates that $\mathrm{AT}_{2}$-receptor would have an organ-protective function during hypovolemia in the small intestines. A study using an $\mathrm{AT}_{1}$-receptor antagonist in pigs during a $40 \%$ total blood volume hemorrhage found increased jejunal perfusion and portal venous flow compared with a control group and increased survival among $\mathrm{AT}_{1}$-receptor antagonist-treated pigs (35).

\section{POSSIBLE ROLE FOR THE ANG(1-7) RECEPTOR}

de Moura et al. have suggested a possible role for $\operatorname{Ang}(1-7)$ receptors in episodes of central hypovolemia, arguing that the augmenting effect of losartan is due to a stimulation of the Ang(1-7)-receptor. They presented evidence that the combined use of losartan with a $\operatorname{Ang}(1-7)$-receptor antagonist leads to a removing of the bradycardic effect of losartan resulting in a blunting of the orthostatic response of losartan (18). Analogously Ryckwaert el al. (20) have suggested that the fall in vascular resistance observed with a $\mathrm{AT}_{1}$-receptor antagonist might originate from increased metabolites, such as Ang(1-7) or Ang(4), which might have vasodilatory properties (53-55).

\section{SYMPATHETIC ACTIONS OF ANGIOTENSIN II DURING EXPERIMENTALLY SIMULATED CENTRAL HYPOVOLEMIA}

The debate about sympathetic stimulation of angiotensin II is centered on the question whether angiotensin II has a central or a peripheral site of action on the sympathetic system during central hypovolemia.

That angiotensin II can have a potentiating effect on the sympathetic system is well-known $(25,56,57)$. Hatton et al. was the first to suggest that angiotensin II has a sympathetic effect during hypovolemia. They observed a prolonged negative effect on arterial pressure during lower body negative pressure with ACE-inhibitors compared with an $\mathrm{AT}_{1}$-receptor antagonist. They further observed that there was not a reduced efferent nerve activity and, hence, suggested a peripheral site of action for angiotensin II (19).

Ohlstein et al's result from head up tilt table test gave the first evidence for a specific $\mathrm{AT}_{1}$-receptor-mediated sympathetic effect during hypovolemia. The accentuated hypotensive effect of losartan led them to suggest that the stimulation of specific receptors at the site of the primary baroreceptor synapse (25). Johansson et al. found that a moderate hemorrhage of $10 \%$ of the total blood volume induced a significant fall of nearly $50 \%$ in mucosal alkaline secretion in rats $(N=18)$. This effect could be reversed by the administration of an $\mathrm{AT}_{1}$-receptor antagonist and elevated by administration of exogenous angiotensin II. This suggested that angiotensin II had a prolonging effect on symphato-adrenergic inhibition of mucosal alkaline secretion acting specifically on efferent secremotor neuron in the intestines
(23). Angiotensin II was administered to ACE-inhibitor-treated animals and a significant inhibitory effect was observed during direct splanchnic nerve stimulation (23). This indicates the presence of a peripheral mechanism of action (23).

Pancera et al's head up tilt table tests in human subjects showed that losartan inhibits the sympathetic activity and maintained vagal activity. This suggests a direct sympathetic function of the $\mathrm{AT}_{1}$-receptor and a vagally inhibitory function of angiotensin II acting peripherally (16).

Using head tilt table, Bedette et al. showed that conscious rats treated with losartan seem to have the same compensatory mechanism as with other $\mathrm{AT}_{1}$-receptor antagonists. Bedette et al. argued that $\mathrm{AT}_{1}$-receptor antagonists can cross the blood-brain barrier and that the reason for an accentuated orthostatic effect of losartan is due to a differentially centrally mediated action of the $\mathrm{AT}_{1}$-receptor antagonists $(22,58)$.

\section{DISCUSSION}

The evidence suggests an organ-protective function of angiotensin II in splanchnic tissue, most prominently the kidney and the intestines. The results of investigating angiotensin II's interaction with the sympathetic system during experimentally simulated central hypovolemia are indicating both centrally and a peripherally mediated inhibition of the baroreflex $(16,23)$.

There is evidence supporting the organ-protective role of the $\mathrm{AT}_{2}$-receptor in studies that are not using one of the three models of hypovolemia (47). As splanchnic ischemia and acute renal failure are recognizable factors in postoperative morbidity (59), a possible protective function yield a number of possible uses for $\mathrm{AT}_{2}$-receptor agonists (60). One promising candidate for an $\mathrm{AT}_{2}$ agonist is the non-peptide "Compound 21" developed by Vicore Pharma AB (61).

Although seemingly not addressed so far, future pharmaceutical use, using one of the models for central hypovolemia might be relevant if further evidence support an organ-protective role during hypovolemia (35) and potentially opening the use of this and other $\mathrm{AT}_{2}$ agonist in hypovolemic therapy.

Ang(1-7) could represent an explanation for some of the vasodilatory actions seen with $\mathrm{AT}_{1}$-receptor antagonists. There are arguments for such an effect, including losartan-sensitive Ang(1-7) receptors, in the heart (62) and kidney $(55,63)$. However, the results contraindicate this finding (64) and de Moura et al.s conclusion is seemingly that the effect is at best minor (18).

Studies have shown both peripheral and central mechanism of Angiotensin II in studies with one of the models of hypovolemia.

Bedette et al.s argue that the effect of $\mathrm{AT}_{1}$ antagonist is obscured by the anesthetic blunting of the sympathetic system. They present the suggestive hypothesis that $\mathrm{AT}_{1}$ antagonists depending on pharmacological specificity might give differential interference with central pre-motor neurons. This cannot be ruled out since the $\mathrm{AT}_{1}$ antagonist is able to pass the blood-brain barrier and could lead to the altered response. However, the anesthetic effect cannot explain the physiological evidence for both centrally $(65-69)$ and some peripheral site of action $(34,70)$ in studies not using one of the three models. 


\section{CONCLUSION}

There is evidence supporting an organ-protective function of the $\mathrm{AT}_{2}$. A study with one of the three accepted models of simulated hypovolemia could be used to verify this, with an $\mathrm{AT}_{2}$ agonist such as compound 21 (61). The verification of an organ-protective function could yield the use of such agents in hypovolemic therapy.

Further studies aimed at distinguishing between a $\mathrm{AT}_{2}$-receptor stimulation and a Ang(1-7) stimulation could prove useful to clarify the presence of a synergistic effect.

There is evidence supporting that the blunting of the baroreflex by angiotensin II is a combination of peripheral and central mechanism and that it is mediated by the $\mathrm{AT}_{1}$-receptor. Future trials investigating angiotensin II's sympathetic actions with one of the three accepted models of simulated hypovolemia would

\section{REFERENCES}

1. Sander-Jensen K, Secher NH, Astrup A, Christensen NJ, Giese J, Schwartz TW, et al. Hypotension induced by passive head-up tilt: endocrine and circulatory mechanisms. Am J Physiol (1986) 251(4 Pt 2):R742-8.

2. Gutierrez G, Reines HD, Wulf-Gutierrez ME. Clinical review: hemorrhagic shock. Crit Care (2004) 8(5):373-81. doi:10.1186/cc2851

3. Kozek-Langenecker SA. Intravenous fluids: should we go with the flow? Crit Care (2015) 19(Suppl 3):S2. doi:10.1186/cc14720

4. Wang J, Liang T, Louis L, Nicolaou S, McLaughlin PD. Hypovolemic shock complex in the trauma setting: a pictorial review. Can Assoc Radiol J (2013) 64(2):156-63. doi:10.1016/j.carj.2013.03.002

5. Barcroft HEO, McMichael J, Sharpey-Shaefer EP. Posthaemorrhagic fainting study by cardiac output and forearm flow. Lancet (1944) 243(6294):489-91. doi:10.1016/S0140-6736(00)74173-0

6. Shenkin HA, Cheney RH, Govons SR, Hardy JD, Fletcher AG Jr, Starr I. On the diagnosis of hemorrhage in man: a study of volunteers bled large amounts. Am J Med Sci (1944) 208(4):421-36. doi:10.1097/00000441-194410000-00001

7. McMichael J. Clinical aspects of shock. J Am Med Assoc (1944) 124(5):275-81. doi:10.1001/jama.1944.02850050007003

8. Grant RT, Reeve EB. Clinical observations on air-raid casualties. Br Med J (1941) 2(4208):293-7. doi:10.1136/bmj.2.4209.329

9. Convertino VA. Lower body negative pressure as a tool for research in aerospace physiology and military medicine. J Gravit Physiol (2001) 8(2):1-14.

10. Moya i Mitjans A, Permanyer-Miralda G, Sagrista Sauleda J, Rius Gelabert T. [The tilt-table test: is it essential for adequate treatment of vasovagal syncope? Arguments in favor]. Rev Esp Cardiol (1997) 50(6):368-73.

11. Nguyen MT, Lee DH, Delpire E, McDonough AA. Differential regulation of $\mathrm{Na}+$ transporters along nephron during ANG II-dependent hypertension: distal stimulation counteracted by proximal inhibition. Am JPhysiol Renal Physiol (2013) 305(4):F510-9. doi:10.1152/ajprenal.00183.2013

12. Zaika O, Mamenko M, Staruschenko A, Pochynyuk O. Direct activation of ENaC by angiotensin II: recent advances and new insights. Curr Hypertens Rep (2013) 15(1):17-24. doi:10.1007/s11906-012-0316-1

13. vanderLubbeN,ZietseR,HoornEJ. Effectsofangiotensin IIonkinase-mediated sodium and potassium transport in the distal nephron. Curr Opin Nephrol Hypertens (2013) 22(1):120-6. doi:10.1097/MNH.0b013e32835b6551

14. Catt KJ, Mendelsohn FA, Millan MA, Aguilera G. The role of angiotensin II receptors in vascular regulation. J Cardiovasc Pharmacol (1984) 6(Suppl 4):S575-86. doi:10.1097/00005344-198406004-00004

15. de Gasparo M, Catt KJ, Inagami T, Wright JW, Unger T. International union of pharmacology. XXIII. The angiotensin II receptors. Pharmacol Rev (2000) 52(3):415-72.

16. Pancera P, Presciuttini B, Sansone S, Montagna L, Paluani F, Covi G, et al. Effect of losartan on heart rate and blood pressure variability during tilt test and trinitroglycerine vasodilation. J Hypertens (1999) 17(4):513-21. doi:10.1097/00004872-199917040-00009 help clarify the exact site of action and the strength of this blunting in hypovolemic patients. Such result is advantageous in determining possible interactions and side effects of future pharmaceutical agents.

\section{AUTHOR CONTRIBUTIONS}

TJ and NO have both contributed to designing and planning the work process. The idea for the article originated from NO. TJ conducted the literature search and first draft in December 2014. In early 2016, NO revised the data and contributed with much of the intellectual and academic input for the second draft. A new search was done in October 2015 , and the final draft was approved by both authors after academic scrutiny.

17. Aneman A, Bengtsson J, Snygg J, Holm M, Pettersson A, Fandriks L. Differentiation of the peptidergic vasoregulatory response to standardized splanchnic hypoperfusion by acute hypovolaemia or sepsis in anaesthetized pigs. Acta Physiol Scand (1999) 166(4):293-300. doi:10.1046/j.1365-201x.1999.00574.x

18. de Moura MM, dos Santos RA, Fontes MA. Evidence for a functional cardiac interaction between losartan and angiotensin-(1-7) receptors revealed by orthostatic tilting test in rats. Br J Pharmacol (2005) 144(6):755-60. doi:10.1038/sj.bjp.0706039

19. Hatton R, Clough DP, Adigun SA, Conway J. Functional interaction between angiotensin and sympathetic reflexes in cats. Clin Sci (Lond) (1982) 62(1):51-6. doi:10.1042/cs0620051

20. Ryckwaert F, Colson PH. Hypovolaemia-induced vasodilatation during angiotensin AT1 receptor blockade: role of the AT2 receptor. Pharmacol Res (2005) 51(1):37-40. doi:10.1016/j.phrs.2004.07.010

21. Ryckwaert F, Colson P, Andre E, Perrigault PF, Guillon G, Barberis C. Haemodynamic effects of an angiotensin-converting enzyme inhibitor and angiotensin receptor antagonist during hypovolaemia in the anaesthetized pig. Br J Anaesth (2002) 89(4):599-604. doi:10.1093/bja/aef221

22. Bedette D, Santos RA, Fontes MA. Cardiovascular reactivity after blockade of angiotensin AT1 receptors in the experimental model of tilting test in conscious rats. Br J Pharmacol (2008) 153(5):966-71. doi:10.1038/sj.bjp.0707652

23. Johansson B, Holm M, Chen L, Pettersson A, Jonson C, Fandriks L. ANG II prolongs splanchnic nerve-mediated inhibition of duodenal mucosal alkaline secretion in the rat. Am J Physiol (1997) 273(3 Pt 2):R942-6.

24. Hashimoto Y, Ohashi R, Minami K, Narita H. Comparative study of TA-606, a novel angiotensin II receptor antagonist, with losartan in terms of species difference and orthostatic hypotension. Jpn J Pharmacol (1999) 81(1):63-72. doi:10.1254/jjp.81.63

25. Ohlstein EH, Gellai M, Brooks DP, Vickery L, Jugus J, Sulpizio A, et al. The antihypertensive effect of the angiotensin II receptor antagonist DuP 753 may not be due solely to angiotensin II receptor antagonism. J Pharmacol Exp Ther (1992) 262(2):595-601.

26. Ferrario CM. ACE2: more of Ang-(1-7) or less Ang II? Curr Opin Nephrol Hypertens (2011) 20(1):1-6. doi:10.1097/MNH.0b013e3283406f57

27. Liu CQ, Huang Y, Lu LM. [Effects of ACE2-Ang 1-7-Mas axis on blood vessel] Sheng Li Ke Xue Jin Zhan (2007) 38(1):43-8.

28. Iwai $M$, Horiuchi $M$. Devil and angel in the renin-angiotensin system: ACE-angiotensin II-AT1 receptor axis vs. ACE2-angiotensin-(1-7)-Mas receptor axis. Hypertens Res (2009) 32(7):533-6. doi:10.1038/hr.2009.74

29. Frank H, Schobel HP, Vitkowsky J, Schmieder RE, Heusser K. Effects of angiotensin II receptor antagonism on the renal hemodynamic response to cardiovascular stress. Kidney Int (2003) 63(2):617-23. doi:10.1046/j.1523-1755.2003.00760.x

30. Stadeager C, Hesse B, Henriksen O, Christensen NJ, Bonde-Petersen F, Mehlsen J, et al. Effects of angiotensin blockade on the splanchnic circulation in normotensive humans. J Appl Physiol (1985) (1989) 67(2):786-91. 
31. Ibsen H, Egan B, Osterziel K, Vander A, Julius S. Reflex-hemodynamic adjustments and baroreflex sensitivity during converting enzyme inhibition with MK-421 in normal humans. Hypertension (1983) 5(2 Pt 2):I184-91. doi:10.1161/01.HYP.5.2_Pt_2.I184

32. Kinugawa T, Kato M, Mori M, Endo A, Kato T, Hamada T, et al. Effects of a new angiotensin-converting enzyme inhibitor, alacepril, on changes in neurohormonal factors and arterial baroreflex sensitivity in patients with congestive heart failure. Eur J Clin Pharmacol (1998) 54(3):209-14. doi:10.1007/ s002280050447

33. Zerbe RL, Feurstein G, Kopin IJ. Effect of captopril on cardiovascular, sympathetic and vasopressin responses to hemorrhage. Eur J Pharmacol (1981) 72(4):391-5. doi:10.1016/0014-2999(81)90583-5

34. Struck J, Muck P, Trubger D, Handrock R, Weidinger G, Dendorfer A, et al. Effects of selective angiotensin II receptor blockade on sympathetic nerve activity in primary hypertensive subjects. J Hypertens (2002) 20(6):1143-9. doi:10.1097/00004872-200206000-00026

35. Aneman A, Svensson M, Broome M, Biber B, Petterson A, Fandriks L. Specific angiotensin II receptor blockage improves intestinal perfusion during graded hypovolemia in pigs. Crit Care Med (2000) 28(3):818-23. doi:10.1097/00003246-200003000-00034

36. Franke WD, Lee K, Buchanan DB, Hernandez JP. Blacks and whites differ in responses, but not tolerance, to orthostatic stress. Clin Auton Res (2004) 14(1):19-25. doi:10.1007/s10286-004-0155-5

37. Laesser M, Spak E, Ewert S, Aneman A, Fandriks L. Candesartan improves survival following severe hypovolemia in pigs; a role for the angiotensin II type 2 receptor? Intensive Care Med (2005) 31(8):1109-15. doi:10.1007/ s00134-005-2686-1

38. Scheuer DA, Perrone MH. Angiotensin type 2 receptors mediate depressor phase of biphasic pressure response to angiotensin. Am J Physiol (1993) 264(5 Pt 2):R917-23.

39. Tidgren B, Hjemdahl P, Theodorsson E, Nussberger J. Renal responses to lower body negative pressure in humans. Am J Physiol (1990) 259(4 Pt 2):F573-9.

40. Hinojosa-Laborde C, Shade RE, Muniz GW, Bauer C, Goei KA, Pidcoke HF, et al. Validation of lower body negative pressure as an experimental model of hemorrhage. J Appl Physiol (1985) (2014) 116(4):406-15. doi:10.1152/ japplphysiol.00640.2013

41. Hirsch AT, Levenson DJ, Cutler SS, Dzau VJ, Creager MA. Regional vascular responses to prolonged lower body negative pressure in normal subjects. Am J Physiol (1989) 257(1 Pt 2):H219-25.

42. Greenleaf JE, Petersen TW, Gabrielsen A, Pump B, Bie P, Christensen NJ, et al. Low LBNP tolerance in men is associated with attenuated activation of the renin-angiotensin system. Am J Physiol Regul Integr Comp Physiol (2000) 279(3):R822-9.

43. Watenpaugh DE, Breit GA, Buckley TM, Ballard RE, Murthy G, Hargens AR. Human cutaneous vascular responses to whole-body tilting, Gz centrifugation, and LBNP. J Appl Physiol (1985) (2004) 96(6):2153-60. doi:10.1152/ japplphysiol.00198.2003

44. Courneya CA, Korner PI. Neurohumoral mechanisms and the role of arterial baroreceptors in the reno-vascular response to haemorrhage in rabbits. J Physiol (1991) 437:393-407. doi:10.1113/jphysiol.1991.sp018602

45. Schadt JC, Ludbrook J. Hemodynamic and neurohumoral responses to acute hypovolemia in conscious mammals. Am J Physiol (1991) 260(2 Pt 2):H305-18.

46. Kitano A, Shoemaker JK, Ichinose M, Wada H, Nishiyasu T. Comparison of cardiovascular responses between lower body negative pressure and head-up tilt. J Appl Physiol (1985) (2005) 98(6):2081-6. doi:10.1152/ japplphysiol.00563.2004

47. Widdop RE, Jones ES, Hannan RE, Gaspari TA. Angiotensin AT2 receptors: cardiovascular hope or hype? Br J Pharmacol (2003) 140(5):809-24. doi:10.1038/sj.bjp.0705448

48. Ichiki T, Labosky PA, Shiota C, Okuyama S, Imagawa Y, Fogo A, et al. Effects on blood pressure and exploratory behaviour of mice lacking angiotensin II type-2 receptor. Nature (1995) 377(6551):748-50. doi: $10.1038 / 377748 \mathrm{a} 0$

49. Carey RM. Update on the role of the AT2 receptor. Curr Opin Nephrol Hypertens (2005) 14(1):67-71. doi:10.1097/00041552-200501000-00011

50. Carey RM. Angiotensin type-2 receptors and cardiovascular function: are angiotensin type-2 receptors protective? Curr Opin Cardiol (2005) 20(4):2649. doi:10.1097/01.hco.0000166596.44711.b4
51. Gohlke P, Pees C, Unger T. AT2 receptor stimulation increases aortic cyclic GMP in SHRSP by a kinin-dependent mechanism. Hypertension (1998) 31(1 Pt 2):349-55. doi:10.1161/01.HYP.31.1.349

52. Siragy HM, Senbonmatsu T, Ichiki T, Inagami T, Carey RM. Increased renal vasodilator prostanoids prevent hypertension in mice lacking the angiotensin subtype-2 receptor. J Clin Invest (1999) 104(2):181-8. doi:10.1172/JCI6063

53. Iyer SN, Chappell MC, Averill DB, Diz DI, Ferrario CM. Vasodepressor actions of angiotensin-(1-7) unmasked during combined treatment with lisinopril and losartan. Hypertension (1998) 31(2):699-705. doi:10.1161/01.HYP.31.2.699

54. Patel JM, Martens JR, Li YD, Gelband CH, Raizada MK, Block ER. Angiotensin IV receptor-mediated activation of lung endothelial NOS is associated with vasorelaxation. Am J Physiol (1998) 275(6 Pt 1):L1061-8.

55. Nematbakhsh M, Safari T. Role of Mas receptor in renal blood flow response to angiotensin (1-7) in male and female rats. Gen Physiol Biophys (2014) 33(3):365-72. doi:10.4149/gpb_2014008

56. Campbell WB, Jackson EK. Modulation of adrenergic transmission by angiotensins in the perfused rat mesentery. Am J Physiol (1979) 236(2):H211-7.

57. Clough DP, Mulroy SC, Angell D, Hatton R. Interference by inhibitors of the renin-angiotensin system with neurogenic vasoconstriction. Clin Exp Hypertens A (1983) 5(7-8):1287-99. doi:10.3109/10641968309048858

58. Sheriff MJ, Fontes MA, Killinger S, Horiuchi J, Dampney RA. Blockade of AT1 receptors in the rostral ventrolateral medulla increases sympathetic activity under hypoxic conditions. Am J Physiol Regul Integr Comp Physiol (2006) 290(3):R733-40. doi:10.1152/ajpregu.00410.2005

59. Bjorck M, Hedberg B. Early detection of major complications after abdominal aortic surgery: predictive value of sigmoid colon and gastric intramucosal $\mathrm{pH}$ monitoring. Br J Surg (1994) 81(1):25-30. doi:10.1002/bjs.1800810108

60. Henrion D. Why do we need a selective angiotensin II type 2 receptor agonist? Hypertension (2012) 60(3):616-7. doi:10.1161/ HYPERTENSIONAHA.112.197046

61. Pharma V, editor. Angiotensin AT2 Receptor (AT2R) Agonists - A New Drug Class. [Online] Available: http://www.vicorepharma.com/archive/files/19352/ Company+incl+ref+oct13.pdf.aspx

62. Metzger R, Bader M, Ludwig T, Berberich C, Bunnemann B, Ganten D. Expression of the mouse and rat mas proto-oncogene in the brain and peripheral tissues. FEBS Lett (1995) 357(1):27-32. doi:10.1016/0014-5793(94)01292-9

63. Gironacci MM, Coba MP, Pena C. Angiotensin-(1-7) binds at the type 1 angiotensin II receptors in rat renal cortex. Regul Pept (1999) 84(1-3):51-4. doi:10.1016/S0167-0115(99)00067-1

64. Sampaio WO, Nascimento AA, Santos RA. Systemic and regional hemodynamic effects of angiotensin-(1-7) in rats. Am J Physiol Heart Circ Physiol (2003) 284(6):H1985-94. doi:10.1152/ajpheart.01145.2002

65. Ferrario CM. Neurogenic actions of angiotensin II. Hypertension (1983) 5(6 Pt 3):V73-9. doi:10.1161/01.HYP.5.6_Pt_3.V73

66. Zimmerman BG. Adrenergic facilitation by angiotensin: does it serve a physiological function? Clin Sci (Lond) (1981) 60(4):343-8. doi:10.1042/cs0600343

67. Mancia G, Parati G, Pomidossi G, Grassi G, Bertinieri G, Buccino N, et al. Modification of arterial baroreflexes by captopril in essential hypertension. Am J Cardiol (1982) 49(6):1415-9. doi:10.1016/0002-9149(82)90353-8

68. Montano N, Gnecchi-Ruscone T, Contini M, Finocchiaro ML, Lombardi F, Malliani A. Effect of captopril on sympathetic preganglionic efferent activity in cats. Am J Physiol (1993) 264(2 Pt 2):H345-51.

69. Campagnole-Santos MJ, Heringer SB, Batista EN, Khosla MC, Santos RA. Differential baroreceptor reflex modulation by centrally infused angiotensin peptides. Am J Physiol (1992) 263(1 Pt 2):R89-94.

70. Lumbers ER, McCloskey DI, Potter EK. Inhibition by angiotensin II of baroreceptor-evoked activity in cardiac vagal efferent nerves in the dog. J Physiol (1979) 294:69-80. doi:10.1113/jphysiol.1979.sp012915

Conflict of Interest Statement: The authors declare that the research was conducted in the absence of any commercial or financial relationships that could be construed as a potential conflict of interest.

Copyright $\odot 2016$ Jensen and Olsen. This is an open-access article distributed under the terms of the Creative Commons Attribution License (CC BY). The use, distribution or reproduction in other forums is permitted, provided the original author(s) or licensor are credited and that the original publication in this journal is cited, in accordance with accepted academic practice. No use, distribution or reproduction is permitted which does not comply with these terms. 